\title{
Exploring Factors Influencing Satisfaction of the University Students Who Work as Private Tutors
}

\author{
Asif Imtiaz ${ }^{1}$ \\ ${ }^{1}$ Department of Management Information Systems, University of Dhaka, Dhaka, Bangladesh \\ Correspondence: Asif Imtiaz, Department of Management Information Systems, University of Dhaka, Dhaka \\ 1000, Bangladesh. Tel: 880-162-875-9566. E-mail: asifimtiaz.mis@du.ac.bd
}

Received: January 12, 2018

Accepted: February 21, $2018 \quad$ Online Published: April 27, 2018

doi:10.5539/ies.v11n5p133

URL: https://doi.org/10.5539/ies.v11n5p133

\begin{abstract}
Private Supplementary Tutoring (PST) have attracted enormous attention in recent days. Bangladesh experiences both forms of PST - formal and informal. There is a considerable amount of research based on the demand-side of PST. The tutors, who are the suppliers of PST in the market, are the center of attention in this paper. The forces that affect the satisfaction of a tutor from providing tuition have been investigated here through factor analysis and stepwise regression. Analyzing a set of tutors from University of Dhaka, tutoring environment and financial independence are found to have a positive relationship with the satisfaction level of a tutor. Transportation costs as well as disadvantageous factors of tutoring as in wasting productive time, hampering academic results, lack of recreation pull the level of satisfaction down. Tutors are thought to be self-concentrated since result and improvement of the tutees are absent from the formulation of their satisfaction. Driving a wedge of fellow feeling between tutors and tutees will enhance the quality of education.
\end{abstract}

Keywords: private supplementary tutoring, shadow education, financial independence, disadvantages, tutoring environment, transportation cost

\section{Introduction}

Educational activities of students' under the supervision of a single teacher or a set of teachers from different disciplines or even in any coaching center after attending regular classes in respective institutions is a widespread phenomenon in our country. This type of private supplementary tutoring after formal schooling hours in which students certainly make payment to the tutors in order to get further assistance is called shadow education (e.g., Stevenson \& Baker, 1992; Bray, 1999, 2009; Bregvadze, 2012). When formal educational institutions start becoming ineffective, private tutoring acts as a surrogate mother (Sujatha, 2014). The shadow education system mimics the regular education system as in any change in the regular education system is followed precisely by the shadow education system (Bray, 2013). Private supplementary tutoring is confined only to academic subjects (Bray, 2003). Private tutors were at work to teach children in economically solvent families even long before the schools were established (Ireson, 2004). Like we hear of Alexander the Great took tuition under Aristotle in Macedon. In England, even in the beginning of the nineteenth century, private tutors were in action in under different forms in all universities (Whewell, 1838). When public education fails to meet the desire for better schooling, parents choose tutoring as a substitute enhancement (Kim \& Park, 2012). An econometric modelling found demand for tutoring depends on the poor state of infrastructure of educational institutions, shirking by most of the teachers and policy implication of the government (B. Saha \& S. B. Saha, 2009). This is partially true in Bangladesh. But in most of the cases, whatever the quality of formal schooling is parents decide to set up a supplementary way of education for their children. Nath (2008) with the support of (Bray, 1999; Bray \& Kwok, 2003; Foondun, 2002) wrote that private supplementary tutoring has stretched all over the universe, both in the developed and the developing countries. In 2007, the estimated spending on private supplementary tutoring was 2\% of GDP of South Korea (Kim \& Park, 2012). Japan and Taiwan have a tall tally of students taking supplementary tuition (Bray \& Lykins, 2012; Liu, 2012). Dang (2011) found around 32\% percent of primary students of Vietnam are taking private tutoring. Besides East Asia, South Asia is experiencing rapid growth of shadow education. In West Bengal of India, at the primary level, almost $57 \%$ of the student went through private supplementary tutoring (Sen, 2010). In Sri Lanka, the tradition of supplementary tutoring is no new (Pallegedara, 2012). In low-income countries in the African region, shadow education already has stepped in and has made its 
root sturdy (Napporn \& Baba-Moussa, 2013). A study in Ethiopia showed school teachers are the ones who give tutoring to their own students might create demand for private supplementary tutoring because of perceived low salary (Melese \& Abebe, 2017). The growth of shadow education can be experienced in North and South America (Sunderman, 2007; Diskin, 2010; Ventura \& Gomes, 2013). In Canada, franchises are the driving force behind the vivid growth and transformation of their tutoring industry and it is much more intensive than traditional shadow education (Aurini \& Davies, 2004). Shadow education expanded notably in Eastern Europe after the political alterations in the late 80 s and early 90 s (Silova, 2010). The correspondence between socio-economic factors and demand for private tutoring among Polish secondary level students were examined by Safarzyńska (2011). In Bangladesh, the plot is nothing different. If one looks past the history of shadow education in Bangladesh, it would be difficult to find the point of starting of this phenomenon. From the older citizens, a term named 'Lodging Master' can be heard of. Lodging master is a poor bur meritorious student of college/university who was recruited by any well-off family to look after the academic activities of the child/children of that family. Lodging masters used to live with their employer-family. These tutors were compensated by both in cash and in-kind (Nath, 2008). The form of lodging master based private tutoring has been transformed and by various steps of evolution has taken the form of modern private supplementary education which includes one-to-one tutoring, provision of tuition in batch, establishing franchises of coaching centers and tuition academies. In Dhaka, maximum numbers of private tutors, coaching teachers are from different universities, especially from the University of Dhaka, the highest echelon of academic excellence in Bangladesh. The factors that motivate these mammoth number of students for giving private tutoring and the consequences of investing time in shadow education needs concentration for sure. The cost and benefits of giving private tuition of students engaged in this activity might be an undiscovered space of research since scholarly articles are not available to the extent one expects. This paper tries to unveil some portions of this unexplored zone of research interest.

\section{Literature Review}

A common understanding behind demanding private supplementary tutoring for children is that parents believe formal schooling is insufficient to develop skills and availing supplementary tutoring for their kids will uphold the probability of their success in examinations. This tendency gets intensified specifically when children are on the verge of any public examination passing which they will enter in a new stage of education. Suppose, students who are studying in watersheds in the education system as grade 8 or grade 10, are more likely to demand private tutoring more than others since they are concerned to secure good examination scores ( Mahmud \& Bray, 2017; Bray \& Lykins, 2012, pp. 23-25). Again, one notable thing is that academically well performing youth are more likely to get into good universities and have well-remunerated job lately while their academically weaker counterparts have less economic prospects. Awareness of this fact stresses students and their parents so that demand for supplementary tutoring comes in the picture (Bray, 2013; Davies \& Guppy, 2010). In countries where teachers feel they are getting a low salary, demand is effectively created by the teachers themselves and parents have little choices over the decision of paying or not paying the fee. This is because those teachers set the questions of the examination and evaluates the answer scripts. Therefore, promotion of pupils to subsequent classes solely relies on the teachers (Bray \& Kwok, 2003). In Bangladesh, students now go through several public examinations such as Primary School Certificate (PSC), Junior School Certificate (JSC), Secondary School Certificate (SSC), Higher Secondary Certificate (HSC), Admission tests of different universities, Bangladesh Civil Service (BCS) examinations. Even in China, provision of private tutoring for diploma programmes can be seen (Wright, Lee, \& Feng, 2017). Interesting observation is that, for each of these examinations, specialized coaching centers are available and one-to-one tutoring and batch tutoring also go on. It implies that, regardless of the class or grades in which students are studying, whatever the institution is, desire for success in the examination is a vital force working behind the demand for supplementary tutoring. Private supplementary tutoring is acquired in exchange for money and richer families obviously are in pole position to occupy good and qualified tutors. Tutoring widens the education gap between rich and poor which in effect can bring social exclusion of the poor (Sweetman, 2002). Because difference in schooling, whether formal or informal like shadow education, can rejuvenate difference in socio-economic class by intertemporal spread of economic, cultural, social capital and advantages (Edgerton, Peter, \& Roberts, 2008). The amount spent on private supplementary tutoring increases with the expenditure level of households which means those who have high standard of living spend much on private tutoring (Pallegedara \& Mottaleb, 2018). Pallegedara and Mottaleb (2018) also have shown that average lifetime of formal schooling of a family affirmatively manipulates the expenditure on shadow education. If we look at private tutoring in English, examining socioeconomic and geographic patterns, it can be seen that tutoring in English is popular among students outside Dhaka and among students from lower socioeconomic class (Hamid, Khan, \& Islam, 2017). This might happen because of the insecurity of parents in terms of success of their children in the examination by competing with their citizen counterparts who are believed to have a head-start in learning English. Again, one 
thing is worth mentioning. That is, occupying private tutors for the children is a dominant strategy for the parents. Whatever the strategy taken by others is, securing a tutor for child/children gives parents a psychological edge over the counterparts. Because they think their children are having higher probability of getting better grades in exam. But the concreteness behind this belief is not justified to the fullest. The effect of private tutoring in academic result is ambiguous (Safarzyńska, 2011). There are two divisions in literature pointing to the dissimilarity in achieving success in the examination using private tutor. A number of studies provide evidence that the students, who receive private classes as in supplementary tutoring, are inclined to get hold of better grades in the examination (Elbaum, Vaughn, Hughes, \& Moody, 2000; Mischo \& Haag, 2002; Tansel \& Birckan, 2005). Some studies found either no significant relationship private supplementary tutoring and educational achievements (Han, Sung, \& Gill, 2001) or negative relationship between participating in supplementary preparatory classes and success in the entrance examination of college (Ban, Jung, \& Yang, 2005).

There has been a lot of research covering the demand side analysis of private supplementary tutoring. But this paper focuses thoroughly on the supply side of this hidden industry. There is certainly a relationship between the educational corruption of teachers and private supplementary tutoring (Bray, 2003). But the teachers by occupation are not the area of concentration in this paper. To be more specific, under-graduation and graduate level students who provide a major share of the tuition hours in the shadow sector of education are the prime foci. Students earn money by giving tuition and sacrifices few hours from his life which could have been employed for their own educational purposes. At the same time, tuition enables them to practice the very basic of their knowledge which can give them a competitive edge in public examinations over their competitors who don't give tuition. The number of university students who offer private supplementary tutoring is huge. This is the most common source of income, if any, of university students irrespective of the institutions in Bangladesh. This paper explores the factors that actually affect the level of satisfaction in the life of tutors derived from providing private supplementary tutoring, who are, especially in this paper, students of graduation and under graduation level from different disciplines of the University of Dhaka.

\section{Objectives of the Study}

The study is, assumedly, maiden step to identify what gives the feeling of contentment in the minds of the tutors. Since Satisfaction is a psychological trait and varies person to person, the prime objective of the study is to give a framework to measure the satisfaction level of tutors while giving tuition. A higher satisfaction will bring the best out of the tutors and the society will be benefited. Again, another goal of the study is to decipher the areas which are needed to be given more concentration and a little treatment to make the tutors well-off so that they can put the highest effort on their duty.

\section{Proposed Theoretical Framework and Variable Definition}

The aim of this paper is to identify the factors which are in action to determine the level of satisfaction of the tutors. A wide range of variables which can exert impact in settling on satisfaction levels of tutors' were identified. Among them, perceived salary; transportation cost; savings; overall environment of the tutoring place (TutEnv in the analysis) which also includes attitude of guardians toward the tutor; potential ability of learning of the students (PotentAbility in the analysis), effort for learning of the students (EffortSS in the analysis), results (ResultsSS in the analysis) and improvement of the students (ImprovementSS in the analysis) after receiving tutoring were readily identified. Since this study is of exploratory type and there is no such literature that can be emulated and modified according to the need of this study, these variables are included on the basis of an attempt to find what can make the tutors ultimately happy from a large basket of related issues.

Besides, the respondents were asked to designate their degree of agreement to the following statements using a 5 -point Likert scale $(1=$ strongly disagree, $5=$ strongly agree $)$. 
Table 1. Coding of variables

\begin{tabular}{lll}
\hline V1 & You Can Contribute Financially to Your Family & FinCont \\
V2 & You Can Satisfy Your Own Needs & OwnNeed \\
V3 & You Can Pay Your Tuition Fees and Living Expenses & TuitFee \\
V4 & You Don't Take Money From Your Family Anymore & NoMonFromFamily \\
V5 & You Have Built A Good Communication With People From Different Layers of the Society & ComSkill \\
V6 & Tuition Will Help You in Passing Competitive Public Exam & CompExam \\
V7 & Earning from Tuition Helps You Maintaining Higher Standard of Living Than Before & StanLiv \\
V8 & Tuition Kills Time & TimeKilling \\
V9 & It Hampers My Academic Result & HampRes \\
V10 & You Don't Have Enough Time for Recreation Due to Tutoring & NoRec \\
V11 & Tutoring Decreases Your Productivity in Both Curricular and Co-curricular Activities & LowProd \\
\hline
\end{tabular}

\section{Method}

This paper is an exploratory nature of the study and follows mixed method (qualitative and quantitative). Non-probabilistic sampling technique (purposive) is used. As there is no sampling frame, the purposive technique was utilized.

Since the university going students supply the lion's share of the total tutoring hour in this arena, a sample size of 150 pupils from them was chosen purposively for the study. Data were collected just after the opening of the semester after a vacation in order to minimize variation in the state of mind of the pupils. The students are from the University of Dhaka and they cover all the groups i.e. science, business studies and humanities in which they had been divided at the time of their corresponding enrollment of SSC Examination.

The instrument of this study is a questionnaire. They were given a semi-structured questionnaire where few questions were open-ended. A range of questions were associated with a 5-point Likert scale ranging from 1 (Strongly Disagree) to 5 (Strongly Agree) as mentioned above in the variable definition section. The level of satisfaction of the tutors, potential ability to learn of the students, effort for learning of the students, results, and improvement of the students after receiving tutoring was measured using the same technique where $1=$ highly dissatisfactory and $5=$ highly satisfactory.

To give the data consistency, we have measured the salary, savings and transportation cost in thousands i.e. the raw data on salary, savings, and transportation cost was divided by 1000. They are named as SalaryDiv, SavingsDiv, and TransDiv respectively in the analysis.

150 questionnaires were distributed online and 148 questionnaires were answered back. 5 responses were omitted due to at least one missing values. Total 143 responses have been taken for the further analysis.

Exploratory factor analysis and stepwise multiple regression techniques were used to analyze the data. All the analysis has been done by SPSS.

\section{Results}

An exploratory factor analysis approach was taken in order to find the interdependency of the data retained from questions V1 to V11. Factor analysis is preferable to Principal Component Analysis and it is nothing but a data lessening method (Costello \& Osborne, 2005). After the extraction of the factors, the factor score coefficients were used for regression analysis along with other variables which were supposed to have relationships with the satisfaction level of the tutors as stated earlier. The level of satisfaction of the tutors is the dependent variable and rests are independent.

\subsection{Principal Component Analysis}

Principal Components Analysis is suggested when the basic concern is to figure out the minimum number of factors that capture maximum variance in the data for bringing into play in the consequent multivariate analysis (Malhotra, 2008). The factors are, basically, the principal components. Data retained from Table 1 as in V1 to V11 are the variables to bring under analysis. Bartlett's test of sphericity rejects the null hypothesis that the population correlation matrix is an identity matrix because the approximate chi-square statistic is 546.883 with 55 degrees of freedom which is significant at the 0.05 level. The value of KMO statistic is 0.719 and since 0.6 is the cut-off value for KMO test (Pallant, 2016), this indicates that factor analysis is suitable. 
Table 2. KMO and Bartlett's test

\begin{tabular}{ccc}
\hline Kaiser-Meyer-Olkin Measure of Sampling Adequacy. & .719 \\
\hline \multirow{4}{*}{ Bartlett's Test of Sphericity } & Approx. Chi-Square & 546.883 \\
& $\mathrm{df}$ & 55 \\
& Sig. & .000 \\
\hline
\end{tabular}

$\mathrm{df}=$ Degrees of Freedom; Sig. $=$ Level of Significance.

Eigenvalue greater than 1.0 is associated with four factors as we see and these four factors account for $72.306 \%$ of total variance. Therefore, four factors, in total, are extracted.

Table 3. Eigenvalues

\begin{tabular}{lccc}
\hline \multirow{2}{*}{ Component } & \multicolumn{3}{c}{ Initial Eigenvalues } \\
\cline { 2 - 4 } & Total & \% of Variance & Cumulative \% \\
\hline 1 & 3.409 & 30.992 & 30.992 \\
2 & 2.375 & 21.592 & 52.584 \\
3 & 1.119 & 10.171 & 62.755 \\
4 & 1.051 & 9.552 & 72.306 \\
5 & .683 & 6.213 & 78.520 \\
6 & .550 & 5.001 & 83.521 \\
7 & .468 & 4.252 & 87.773 \\
8 & .433 & 3.939 & 91.712 \\
9 & .395 & 3.591 & 95.303 \\
10 & .295 & 2.682 & 97.985 \\
11 & .222 & 2.015 & 100.000 \\
\hline
\end{tabular}

Rotated component matrix tells us three variables i.e. financial contribution to the family, communication skill and a higher standard of living than before are crossloading items and thus are dropped.

Table 4. Rotated component matrix

\begin{tabular}{|c|c|c|c|c|}
\hline & \multicolumn{4}{|c|}{ Component } \\
\hline & 1 & 2 & 3 & 4 \\
\hline FinCont & -.007 & .659 & -.082 & .404 \\
\hline OwnNeed & -.017 & .812 & .190 & -.075 \\
\hline TuitFee & -.028 & .799 & .163 & .138 \\
\hline NoMonFromFamily & -.035 & .138 & .122 & .891 \\
\hline ComSkill & -.168 & .369 & .568 & .450 \\
\hline CompExam & -.185 & -.057 & .780 & .280 \\
\hline StanLiv & -.010 & .395 & .788 & -.229 \\
\hline TimeKilling & .825 & -.073 & .119 & -.086 \\
\hline HampRes & .837 & .009 & -.172 & -.093 \\
\hline NoRec & .852 & -.054 & -.088 & .014 \\
\hline LowProd & .821 & .039 & -.181 & .032 \\
\hline
\end{tabular}

Dropping those three crossloading items, same steps were taken again. Bartlett's test of sphericity rejected the null hypothesis once again and the value of KMO statistic was more than 0.719 . Two factors were extracted since their corresponding eigenvalues were more than 1.0. From the rotated component matrix we find the variable Tuition Helps Passing Competitive Exam (V6) crossloads over two factors and it was excluded from the model. 
Table 5. Rotated component matrix after offloading 3 variables those crossload

\begin{tabular}{lcc}
\hline \multirow{2}{*}{ OwnNeed } & \multicolumn{2}{c}{ Component } \\
\cline { 2 - 3 } TuitFee & .032 & .757 \\
NoMonFromFamily & -.083 & .0771 \\
CompExam & -.333 & .375 \\
TimeKilling & .788 & -.035 \\
HampRes & .853 & -.094 \\
NoRec & .851 & -.046 \\
LowProd & .835 & -.028 \\
\hline
\end{tabular}

Principal Component Analysis was done again and Bartlett's test of sphericity rejects the null hypothesis that the population correlation matrix is an identity matrix because the approximate chi-square statistic is 320.262 with 21 degrees of freedom which is significant at 0.05 level. The value of KMO statistic is 0.724 which is greater than 0.5 and indicates that factor analysis is suitable and even better if used than before.

Two factors were extracted because of their eigenvalues were more than 1.0. The rotated component matrix tells factor 1 is correlated with $\mathrm{V} 8, \mathrm{~V} 9, \mathrm{~V} 10$, and $\mathrm{V} 11$ since the absolute value of their respective factor loadings were more than 0.3. Again, V2, V3, V4 are associated with factor 2.

Table 6. Rotated component matrix after omitting V6

\begin{tabular}{lcc}
\hline & \multicolumn{2}{c}{ Component } \\
\cline { 2 - 3 } & 1 & 2 \\
\hline OwnNeed & .006 & .794 \\
TuitFee & -.018 & .854 \\
NoMonFromFamily & -.086 & .537 \\
TimeKilling & .801 & -.051 \\
HampRes & .857 & -.084 \\
NoRec & .855 & -.039 \\
LowProd & .834 & -.011 \\
\hline
\end{tabular}

We can name factor 1 as the 'Disadvantageous Factor' and factor 2 may be labeled as 'Financial Independence' Factor. Killing productive time, hamper of the academic result, lack of recreation and lower productivity due to engagement in private tuition have high loadings on factor 1 . As they all reflect the disadvantages of private tuition, factor 1 is named 'Disadvantageous Factor'. Again, the power of fulfilling own need, ability to give own tuition fee in the university and facing no obligation of taking money from family have high loadings on factor 2 . All these three variables are portrayer of financial independence. Therefore, we name factor 2 as 'Financial Independence Factor'. Component Score Coefficients were retrieved for use in regression analysis.

\subsection{Regression Analysis}

We consider the model:

SatisfactionLevel $=\beta 1+\beta 2($ SalaryDiv $)+\beta 3($ DevTime $)+\beta 4($ TutEnv $)+\beta 5($ ImproveSS $)+\beta 6($ ResultSS $)+\beta 7$ (PotentAbility) $+\beta 8$ (TransDiv) $+\beta 9$ (SavingsDiv) $\beta 10$ (EffortSS) $+\beta 11$ (Disadvantageous Factor) $+\beta 12$ (Financial Independence Factor)

Since there was no a priori knowledge to construct the model, all possible variables that could influence the level of satisfaction of the tutors were installed. Stepwise regression was the tool used to find the exact relationship between the regressand (the dependent variable) and regressors if there were any. 
Table 7. Criteria of entering a variable in stepwise regression

\begin{tabular}{lll}
\hline Model & Variables Entered & \multicolumn{1}{c}{ Method } \\
\hline 1 & TutEnv & Stepwise (Criteria: Probability-of-F-to-enter $<=.050$, Probability-of-F-to-remove $>=.100)$. \\
2 & TransDiv & Stepwise (Criteria: Probability-of-F-to-enter $<=.050$, Probability-of-F-to-remove $>=.100)$. \\
3 & Disadvantageous Factor & Stepwise (Criteria: Probability-of-F-to-enter $<=.050$, Probability-of-F-to-remove $>=.100)$. \\
4 & Financial Independence Factor & Stepwise (Criteria: Probability-of-F-to-enter $<=.050$, Probability-of-F-to-remove $>=.100)$. \\
\hline
\end{tabular}

At each stage, the largest p-value over 0.05 was removed. Only four variables remained and according to the regression, these variables construct the actual model which can explain the level of satisfaction of the tutors associated with private supplementary tutoring. The predictors that are significant statistically are Tutoring Environment, Transportation Cost, Disadvantageous Factor and Financial Independence Factor.

Table 8. Model summary

\begin{tabular}{|c|c|c|c|c|c|c|c|c|c|c|}
\hline \multirow[b]{2}{*}{ Model } & \multirow[b]{2}{*}{$\mathrm{R}$} & \multirow[b]{2}{*}{$\begin{array}{c}\mathrm{R} \\
\text { Square }\end{array}$} & \multirow[b]{2}{*}{$\begin{array}{l}\text { Adjusted R } \\
\text { Square }\end{array}$} & \multirow{2}{*}{$\begin{array}{l}\text { Std. Error of the } \\
\text { Estimate }\end{array}$} & \multicolumn{5}{|c|}{ Change Statistics } & \multirow[b]{2}{*}{ Durbin-Watson } \\
\hline & & & & & $\begin{array}{c}\text { R Square } \\
\text { Change }\end{array}$ & $\begin{array}{c}\text { F } \\
\text { Change }\end{array}$ & df1 & df 2 & $\begin{array}{c}\text { Sig. F } \\
\text { Change }\end{array}$ & \\
\hline 1 & $.666^{\mathrm{a}}$ & .443 & .439 & .63397 & .443 & 112.120 & 1 & 141 & .000 & \\
\hline 2 & $.688^{\mathrm{b}}$ & .473 & .466 & .61864 & .030 & 8.077 & 1 & 140 & .005 & \\
\hline 3 & $.708^{\mathrm{c}}$ & .501 & .490 & .60421 & .028 & 7.766 & 1 & 139 & .006 & \\
\hline 4 & $.722^{\mathrm{d}}$ & .522 & .508 & .59374 & .021 & 5.947 & 1 & 138 & .016 & \\
\hline \multicolumn{5}{|c|}{ a. Predictors: (Constant), TutEnv } & & & & & & 1.956 \\
\hline \multicolumn{10}{|c|}{ b. Predictors: (Constant), TutEnv, TransDiv } & \\
\hline \multicolumn{5}{|c|}{ c. Predictors: (Constant), TutEnv, TransDiv, REGR factor score } & 1 for analysis 3 & & & & & \\
\hline \multicolumn{5}{|c|}{ d. Predictors: (Constant), TutEnv, TransDiv, REGR factor score } & 1 for analysis 3 & REGR fac & or score & 2 & & \\
\hline
\end{tabular}

The multiple regression model with all four variables that passed the criterion mentioned above to be entered into the model produced $\mathrm{R}^{2}=0.522, \mathrm{~F}(4,138)=37.676, \mathrm{p}<0.05$. That is these four predictors were able to account for 52 percent of variation in satisfaction level of the tutors.

Table 9. Coefficients of regression

\begin{tabular}{|c|c|c|c|c|c|c|c|}
\hline \multirow{2}{*}{\multicolumn{3}{|c|}{ Model }} & \multicolumn{2}{|c|}{ Unstandardized Coefficients } & \multirow{2}{*}{$\begin{array}{c}\text { Standardized Coefficients } \\
\text { Beta }\end{array}$} & \multirow{2}{*}{$\mathrm{t}$} & \multirow{2}{*}{ Sig. } \\
\hline & & & $\mathrm{B}$ & Std. Error & & & \\
\hline \multirow{5}{*}{4} & (Constant) & & 1.498 & .257 & & 5.821 & .000 \\
\hline & TutEnv & & .592 & .067 & .563 & 8.883 & .000 \\
\hline & TransDiv & & -.213 & .062 & -.208 & -3.427 & .001 \\
\hline & REGR factor score & 1 for analysis 3 & -.150 & .051 & -.177 & -2.956 & .004 \\
\hline & REGR factor score & 2 for analysis 3 & .129 & .053 & .152 & 2.439 & .016 \\
\hline
\end{tabular}

From the table, it is easily identified that Tutoring Environment has significant positive regression weights demonstrating the fact that the better the overall environment of tutoring place/ tutoring environment, the higher the level of satisfaction of the tutors from supplying tuition if all other variables remain constant that is a $100 \%$ percent improvement in tutoring environment will raise the level of satisfaction by almost $60 \%$ on an average set par. Transportation cost is also important and carries negative regression coefficient which means a lower transportation cost is better for uplifting the satisfaction level controlling for the other variables in the model. The Disadvantageous Factor bears the same relationship as transportation cost with the level of satisfaction. The Financial Independence factor, though a bit low in magnitude, has a positive relationship with the level of satisfaction

\section{Discussion}

The primary objective of this paper is to figure the fact out that what influences the contentment mined from providing supplementary tutoring. The benefits from giving supplementary tuition were largely financial as the 
financial gain from the tutoring is supposed to enhance the standard of living of the tutors and give them economic freedom so that they can pay out of their own and fulfill his own need. Even if giving tuition doesn't let them enjoy the economic freedom to the fullest, still, it will push them distance toward a freedom of living on their own. The costs associated with the provision of tutoring are mostly self-oriented and many of them cannot be measured in monetary terms instantly. We can measure transportation cost, devoted hours with some numbers but the Disadvantageous Factors are least relatable with direct monetary terms possessing a myopic view. But if we dig deep into the philosophy of the asked questions toward them regarding their destruction of time, hamper in academic results, loss of productivity and lack of recreation, it is easily understood that these Disadvantageous Factors actually are lowering down the must-needed attributes the tutors require to boost them up to a new socio-economic scale from where they are now.

The tutors, who were surveyed, all of whom are students of the University of Dhaka, responded in a way where their satisfaction levels don't lay upon the base of financial contribution to their family. Rather most of them don't take money from their family, pay their tuition fees and satisfy their own needs by their income. In effect, this scenario can be a substitute for the direct intrusion of tutoring-earned money in the family income flow. Because earning members of families don't need to outlay a payroll to the tutor's hand like they used to do before the tutors started tutoring, the amount of money saved by the families is somehow equivalent to the 'not-happened' financial contribution by the tutors to their families. Injection and leakage both are absent from the 'circular flow of income of the family' and families are better off than before due to less spending on a person who is independent financially now, somehow. If the tutors' provide the family with financial assistance, which will be a bonus gain and tutors' families will certainly enjoy a less constraint in their budget spending. Since their financial independence benefits them straightaway and their family in a passive approach, the Financial Independence Factor enhances their satisfaction level associated with giving supplementary tuition.

The tutors are concerned about the opportunity costs associated with tutoring. The time they spend on tutoring incurs certain opportunity costs like instead of tutoring they could devote the hours on their academic activities to gain high CGPA which in turn would help them to get into their desired jobs. Again, they feel tutoring lessens their productivity since they get busy with the preparations of what they are going to teach. They cannot put uninterrupted concentration in any work on the days when they have the time fixed for tuitions. A good CGPA and a creative mind, however, are two of the keys to success in early life. Lack of recreation is a big disadvantage coming from engaging in tuition. Tutors expend several hours in tuition and in living place-tutoring place-living place pathway thus their lives become nothing but a routinely mechanized event-schedule. The less these disadvantages, the more the tutors are satisfied. Besides these abstract mental costs in relation to Disadvantageous Factor, financial costs like transportation cost also exert straight blow up in the satisfaction level of the tutors. A $100 \%$ reduction in transportation cost will raise the satisfaction level almost $21 \%$.

Surprisingly, the force matters most in satisfying the tutor is the tutoring environment. The sphere of tutoring environment is big. It majorly covers the place where the event of private supplementary tuition takes place, the attitude and behavior of student's/students' guardians, the ambiance of the tutoring place, relative flexibility given to the tutor. The ultimate satisfaction of the tutors relying on the tutoring environment once again has signified the fact that tutors put much weight on non-financial objects when designating their level of satisfaction from tutoring. If the tutors get a cozy space to give lesson, if the parents of the tutees are cordial and don't interfere illogically and for no reasons into the learning process, if the guardians of the tutees are sympathetic to the difficulties the tutors face in case, if the tutors are given enough freedom to deliver their lesson, the tutoring environment could be said well. Hence, this tutoring environment largely manipulates their level of satisfaction.

The effort, learning ability, result and improvement of the tutees don't have any significant relationship with tutors' satisfaction level. The general thinking is tutors become happy and satisfied when the tutees constantly perform well and try to learn something new. Even tutors feel relieved when the learning ability of the tutees is well. Nevertheless, this specific finding of the research was off the mark from the common shape of thinking.

The amount of payment the tutors receive at the end of month/contract period also has no discriminating effect on the satisfaction level, not even the amount of savings they make. One thing can be assumed here that any uprising in the salary or savings might result in the same way as they lead their life now. Therefore any change in salary and savings will not make their lifestyle or their financial approach toward lives of themselves and their families deviated from what they enjoy and hold now.

\section{Implications}

Tutoring environment and financial independence have a positive relationship with the satisfaction level of tutors. Then again up going disadvantages from tutoring and high transportation cost are expected to lift the 
discontentment of the tutors up. Disadvantages typically engulf consequences arise from opportunity costs of time devoted to tutoring such as killing productive time, hindrance in academic success, less recreation, and loss of creativity. As expected, keeping transportation cost lower is better for the tutors.

The astonishing fact was found in the analysis of affirmative dynamics behind satisfaction level. Tutors were exposed to be much more concentrated on them than the magnitude expected. Any variable related to students like their result, the ability of learning, effort, and improvement had no significant relationship with tutors' satisfaction. Rather, a good tutoring environment ensured by the tutees' guardian/ coaching centers played a pivotal role. Independence in terms of money spending also was vital to inspire the tutors to give tuition. These variables are simply circling the tutor himself who is in the center.

The study can take us to a philosophy that the two parties involved in tutoring- the tutees and the tutors- are no way involved between them other than of their self-interest. One stakeholder is assumed to be concerned solely about their children's result and academic advancement, another stakeholder is worried about their cost and benefit. The guardians/coaching centers which provide the tutors with a good environment which in turn means sympathy to the tutors, tutors find super happiness devoting their hours there.

But again, in those cases also, tutors don't count the positive academic dynamics of the tutees as a factor of their happiness. The arena of private supplementary tutoring has become an example of a homegrown corporation where employers and employees have less mental connections in general and linked together only in terms of self-interest. If the tutors could attach themselves mentally with the tutees' well-being, if they think tutees' success as their success, and if they can form their satisfaction as a function of their students' improvement, happiness will go beyond the boundary of financial cost-benefit.

Though the zero relationship of savings and salary with a satisfaction level of tutors is factually ambiguous, still it can have some insight. Salary and savings had no power on formulating pleasure of the tutors. One reason might be that they think the amount they get from tutoring is transitory income and it is not permanent. The amount needed to gain the financial independence is the benchmark and anything more than this benchmark amount is of no use for them. Tutors are of young ages and most of them have no certain family burdens or responsibilities. They enjoy the time they are living right now and savings is an opposite force which resists living the moment. That is why savings is absent when tutors think about what matters behind their satisfaction.

\section{Conclusion}

This type of study is first of its kind in the history of Bangladesh. Exploring the forces which drive the satisfaction level of providers of private supplementary tutoring was the main idea of this paper. A set of tutors from the University of Dhaka was chosen purposively. By running factor analysis successively, two factors that influence the satisfaction level of the private tutors were found. One is the Disadvantageous Factor and the other is Financial Independence Factor. Besides these two factors, tutoring environment and transportation cost have the authority to manipulate the satisfaction level of tutors. Disadvantages coming from devoting hours in tuition and transportation cost are allied in a negative manner with the level of satisfaction of the tutors. Whereas bringing financial independence in and making tutoring environment better boost their happiness. The tutors are less thoughtful on the success, improvement of the tutees and their enjoyment have nothing significant in terms of the relationship with the payment they get and the amount they save for future. The study was concentrated among the students of the University of Dhaka. The scenario may change as the institution varies. Pupils of different universities possibly will share different perceptions regarding perceived satisfaction. The future direction of research can be pointed toward a massive analysis of graduation and under-graduation level students of different public and private universities who earn by providing private supplementary tutoring.

\section{References}

Aurini, J., \& Davies, S. (2004). The transformation of private tutoring: Education in a franchise form. The Canadian Journal of Sociology, 29(3), 419-438. https://doi.org/10.1353/cjs.2004.0031

Ban, S., Jung, S., \& Yang, S. (2005). Analyzing the effect of private tutoring on academic achievement. Paper presented at the first Korean Education and Employment Panel conference, Seoul, Korea.

Bray, M. (1999). The shadow education system: Private tutoring and its implications for planners. Paris: Unesco, International Institute for Educational Planning.

Bray, M. (2003). Adverse effects of private supplementary tutoring: Dimensions, implications, and government responses. UNESCO. Instituto Internacional de Planeamiento de la Educacion.

Bray, M. (2013). Shadow education: Comparative perspectives on the expansion and implications of private 
supplementary tutoring. Procedia-Social and Behavioral Sciences, 77, $412-420$. https://doi.org/10.1016/j.sbspro.2013.03.096

Bray, M., \& Kwok, P. (2003). Demand for private supplementary tutoring: conceptual considerations, and socio-economic patterns in Hong Kong. Economics of Education Review, 22(6), 611-620. https://doi.org/10.1016/S0272-7757(03)00032-3

Bray, M., \& Lykins, C. (2012). Shadow education: Private supplementary tutoring and its implications for policy makers in Asia (No. 9). Asian Development Bank.

Bray, T. M. (2009). Confronting the shadow education system: What government policies for what private tutoring? United Nations Educational, Scientific and Cultural Organization; International Institute for Educational Planning.

Bregvadze, T. (2012). Analysing the Shadows: Private Tutoring as a Descriptor of the Education System in Georgia. International Education Studies, 5(6), 80-89. https://doi.org/10.5539/ies.v5n6p80

Costello, A. B., \& Osborne, J. W. (2005). Best practices in exploratory factor analysis: Four recommendations for getting the most from your analysis. Practical assessment, research \& evaluation, 10(7), 1-9.

Dang, H. A. (2011). A bird's-eye view of the private tutoring phenomenon in Vietnam. IIAS Newsletter, 56, 26-27.

Davies, S., \& Guppy, N. (2010). The schooled society: An introduction to the sociology of education. Oxford University Press. 198 Madison Avenue, New York, NY 10016.

Diskin, K. S. (2010). Private tutoring: An intersection of economic interests and social capital. Walden University.

Edgerton, J. D., Peter, T., \& Roberts, L. W. (2008). Back to the basics: Socio-economic, gender, and regional disparities in Canada's educational system. Canadian Journal of Education/Revue canadienne de l'éducation, 861-888.

Elbaum, B., Vaughn, S., Tejero Hughes, M., \& Watson Moody, S. (2000). How effective are one-to-one tutoring programs in reading for elementary students at risk for reading failure? A meta-analysis of the intervention research. Journal of educational psychology, 92(4), 605. https://doi.org/10.1037/0022-0663.92.4.605

Foondun, A. R. (2002). The issue of private tuition: an analysis of the practice in Mauritius and selected South-East Asian countries. International review of Education, 48(6), 485-515. https://doi.org/10.1023/A:1021374811658

Hamid, M. O., Khan, A., \& Islam, M. M. (2017). The spread of private tutoring in English in developing societies: exploring students' perceptions. Discourse: Studies in the Cultural Politics of Education, 1-19. https://doi.org/10.1080/01596306.2017.1308314

Han, D., Sung, B., \& Gil, I. (2001). A Study on the Comparison Between the Effects of Private Tutoring versus In-School Education on Academic Acheivement of High School Students. Korean Journal of Sociology of Education, 11(1), 33-54.

Ireson, J. (2004). Private tutoring: how prevalent and effective is it?. London Review of Education, 2(2), 109-122. https://doi.org/10.1080/1474846042000229458

Kim, K. M., \& Park, D. (2012). Impacts of urban economic factors on private tutoring industry. Asia Pacific Education Review, 13(2), 273-280. https://doi.org/10.1007/s12564-011-9192-7

Liu, J. (2012). Does cram schooling matter? Who goes to cram schools? Evidence from Taiwan. International Journal of Educational Development, 32(1), 46-52. https://doi.org/10.1016/j.ijedudev.2011.01.014

Mahmud, R., \& Bray, M. (2017). School factors underlying demand for private supplementary tutoring in English: urban and rural variations in Bangladesh. Asia Pacific Journal of Education, 1-11. https://doi.org/10.1080/02188791.2017.1321525

Malhotra, N. K. (2008). Marketing research: An applied orientation (5th ed.). Pearson Education India. https://doi.org/10.1108/S1548-6435(2008)4

Melese, W., \& Abebe, M. (2017). Demand and Supply of Supplementary Private Tutoring in Upper Primary Schools of Ethiopia. International Online Journal of Educational Sciences, $9(3)$. https://doi.org/10.15345/iojes.2017.03.004

Napporn, C., \& Baba-Moussa, A. R. (2013). Accompagnement et soutien scolaires: l'expérience béninoise. 
Revue internationale d'éducation de Sèvres, 62, 79-88. https://doi.org/10.4000/ries.3120

Nath, S. R. (2008). Private supplementary tutoring among primary students in Bangladesh. Educational Studies, 34(1), 55-72. https://doi.org/10.1080/03055690701785285

Pallant, J. (2016). SPSS Survival Manual: A Step by Step Guide to Data Analysis Using SPSS for Windows (5th ed.). McGraw-Hill Education

Pallegedara, A. (2012). Demand for private tutoring in a free education country. The case of Sri Lanka. International Journal of Education Economics and Development, 3(4), 375-393. https://doi.org/10.1504/IJEED.2012.052321

Pallegedara, A., \& Mottaleb, K. A. (2018). Patterns and determinants of private tutoring: The case of Bangladesh households. International Journal of Educational Development, 59, 43-50. https://doi.org/10.1016/j.jijedudev.2017.10.004

Safarzyńska, K. (2011). Socio-economic determinants of demand for private tutoring. European Sociological Review, 29(2), 139-154. https://doi.org/10.1093/esr/jcr045

Saha, B., \& Saha, S. B. (2009). Private tutoring, school education and government policy. Review of Market Integration, 1(3), 375-408. https://doi.org/10.1177/097492921000100305

Sen, A. (2010). Primary Schooling in West Bengal. Prospects, 40(3), 311-320. https://doi.org/10.1007/s11125-010-9164-4

Silova, I. (2010). Private tutoring in Eastern Europe and Central Asia: Policy choices and implications. Compare, 40(3), 327-344. https://doi.org/10.1080/03057920903361926

Stevenson, D. L., \& Baker, D. P. (1992). Shadow education and allocation in formal schooling: Transition to university in Japan. American journal of sociology, 97(6), 1639-1657. https://doi.org/10.1086/229942

Sujatha, K. (2014). Private tuition in India: trends and issues. Revue internationale d'éducation de Sèvres.

Sunderman, G. L., \& Kim, J. (2007). Increasing Bureaucracy or Increasing Opportunities? School District Experience with Supplemental Educational Service. Revised. Civil Rights Project at Harvard University (The).

Sweetman, A. (2002). Working smarter: education and productivity. In Banting, K., Sharpe, A., and St-Hilaire, F. (Eds.), The review of economic performance and social progress (pp. 157-180). Montreal, QC: The Institute for Research on Public Policy, Centre for the Study of Living Standards.

Tansel, A., \& Bircan-Bodur, F. (2005). Effect of private tutoring on university entrance examination performance in Turkey. IZA Working Discussion Paper no. 1609.

Ventura, A., \& Gomes, C. (2013). Supplementary education in Brazil: Diversity and paradoxes. In Out of the shadows: The global intensification of supplementary education (pp. 129-151). Emerald Group Publishing Limited. https://doi.org/10.1108/S1479-3679(2013)0000022006

Whewell, W. (1838). Of private tutors. In On the principles of English university education (pp. 70-75). London: J.W. Parker.

Wright, E., Lee, M., \& Feng, S. (2017). Shadowing the International Baccalaureate: private supplementary tutoring for the diploma programme in China. Educational Research for Policy and Practice, 1-17. https://doi.org/10.1007/s10671-017-9221-3

\section{Appendix}

The questionnaire was prepared and distributed using Google Form. So the link of the questionnaire derived from Google drive has been given here.

https://goo.gl/forms/doz1 JkgNj5FWeQ2L2

\section{Copyrights}

Copyright for this article is retained by the author(s), with first publication rights granted to the journal.

This is an open-access article distributed under the terms and conditions of the Creative Commons Attribution license (http://creativecommons.org/licenses/by/4.0/). 